\title{
Intercellular contact-dependent survival of human A549, NCl-H596 and NCl-H520 non-small cell lung carcinoma cell lines
}

M.A.A. Castro ${ }^{1,2,3}$,

G. Schwartsmann ${ }^{2}$ and J.C.F. Moreira ${ }^{3}$

\section{Correspondence}

J.C.F. Moreira

Departamento de Bioquímica ICBS, UFRGS

Rua Ramiro Barcelos, 2600, anexo 90035-003 Porto Alegre, RS

Brasil

Fax: + 55-51-316-5535

E-mail: jcfm@ vortex.ufrgs.br

Research supported by CNPq, SO AD and FINEP.

Received October 4, 2000 Accepted May 15, 2001

\author{
'Universidade Luterana do Brasil, Canoas, RS, Brasil \\ ${ }^{2}$ South-American O ffice for Anticancer D rug D evelopment, \\ Hospital de Clínicas de Porto Alegre, and \\ ${ }^{3}$ Departamento de Bioquímica, Universidade Federal do Rio Grande do Sul, \\ Porto Alegre, RS, Brasil
}

\section{Abstract}

In the present study, we examined the relationship between cell phenotype and cell survival of three human non-small cell lung carcinoma cell lines (A549, NCI-H596 and NCI-H520). Cells in exponential growth at various densities were incubated for $24 \mathrm{~h}$ at $37^{\circ} \mathrm{C}$ in a $5 \% \mathrm{CO}_{2}$ humidified atmosphere and then exposed to $\mathrm{UV}$ radiation for $1 \mathrm{~min}(256 \mathrm{~nm}, 40 \mathrm{~W}$, source-to-target distance $100 \mathrm{~cm})$. After two days the surviving cells were quantified by sulforhodamine B staining and DNA fragmentation assay. The differences in UV sensitivity at $60 \times 10^{3}$ cells $/ \mathrm{cm}^{2}$ among the cell lines were not related to the proliferative state of the cells but to the extent of intercellular contact. In contrast to A549 and NCI-H596, irradiated NCI-H520 cells presented lower DNA fragmentation and an aggregated cell culture phenotype even prior to confluence, suggesting that a contact-effect mechanism provides further protection against UV radiation.
Key words

- Non-small cell lung carcinoma

- Cell density

- Intercellular contact

- Cell phenotype

- UV radiation

\section{Introduction}

Cell phenotype and intercellular contacts are intimately related to cell behavior. Cells sense environmental stimuli and respond via morphological modulation (1). For example, it is well known that DNA synthesis gradually stops as cells become confluent and that mitosis continues for some time after cellcell contact (2). According to Chen et al. (3), cell shape compression of confluent cells controls this contact-dependent growth inhibition rather than cell-extracellular matrix contacts or integrin receptor mobilization. The progressive loss of cell shape- and/or cell contact-dependent regulation may lead to the uncontrolled pattern of growth typical of malignant neoplasia (4). However, a number of transformed cell lines continue to exhibit some degree of contact regulation, since isolated tumor cells are far more sensitive to a variety of chemotherapeutic agents than small cell clusters, regardless of the cell cycle distribution or cell proliferative status (for a review, see 5). Moreover, previous studies have shown that the loss of intercellular contact can activate death signals in colon carcinoma (6) and T lymphoma cells (7). Death, triggered by the loss of cell-cell contacts, could serve as a physiological tumor control mechanism by deleting these aberrant cells. Therefore, intercellular adhesion potential and cell culture phenotype might be comparative standards of malig- 
nancy among tumor cells.

We have shown that cell phenotype modulation can interfere with the kinetic growth of three human non-small cell lung carcinoma cell lines (8). In spite of the inherent differences among the cell lines (i.e., coupling potential, growth kinetic, UV sensitivity) we observed that the simulation of an equivalent cell culture phenotype leads to equivalent cell behavior.

In the present study, the tumor phenotype of the same three non-small cell lung carcinoma cell lines (A549, NCI-H596 and NCIH520) was examined on the basis of the cell distribution inside the cultured area. These cells were irradiated with UV light at several densities and one density was identified at which the cell lines displayed the highest differences in UV sensitivity $\left(60 \times 10^{3}\right.$ cells/ $\mathrm{cm}^{2}$ ). At this density, cells exhibited enhanced resistance only in aggregated cell cultures since dispersed cells presented intense DNA fragmentation.

\section{Material and Methods}

The human non-small cell lung carcinoma cell lines A549, NCI-H596 and NCIH520 were obtained from the American Type Culture Collection (Rockville, MD, USA). All cell lines exhibit squamous differentiation by light microscopy criteria (i.e., intracellular keratin, intercellular bridging, "pearl" formation, and/or individual cell keratinization) (9-11). All cell lines grew as an adherent monolayer in $25-\mathrm{cm}^{2}$ culture flask when maintained in RPMI 1640 medium supplemented with $10 \%$ FCS (v/v). NCI-H520 also grew as cellular foci when cultured at densities higher than $30 \times 10^{3}$ cells $/ \mathrm{cm}^{2}$. Log phase cultures were maintained at $37^{\circ} \mathrm{C}$ in a $5 \% \mathrm{CO}_{2}$ humidified atmosphere.

Trypsin treatment was carried out at $37^{\circ} \mathrm{C}$ for 2 min with a mixture of $0.05 \%(\mathrm{w} / \mathrm{v})$ trypsin and $0.02 \%(\mathrm{w} / \mathrm{v})$ EDTA. After trypsinization, cells were counted in a hemocytometer chamber, diluted to appropriate num- bers and seeded at densities of $20 \times 10^{3}$ to $180 \times 10^{3} \mathrm{cells} / \mathrm{cm}^{2}$.

Cell cultures and UV radiation experiments were performed on 96-well and 6well culture plates. Cells were incubated at $37^{\circ} \mathrm{C}$ in a $5 \% \mathrm{CO}_{2}$ humidified atmosphere for $24 \mathrm{~h}$ and then UV irradiated with a Philips UV lamp (256 nm, $40 \mathrm{~W}, 100 \mathrm{~cm}$ source-totarget distance) (8). Cells were washed twice with HBSS buffer and UV irradiated at room temperature for $1 \mathrm{~min}$ (perpendicularly to the light source to avoid penumbra). The medium was replenished and cells were subsequently incubated for an additional period of $48 \mathrm{~h}$. The surviving cell fraction was determined by the sulforhodamine $\beta$ (SRB)staining assay as described elsewhere (12). Briefly, adherent cell cultures were fixed in situ by adding $50 \mu \mathrm{l}$ of cold $50 \%(\mathrm{w} / \mathrm{v})$ trichloroacetic acid (TCA) (final concentration, $10 \% \mathrm{TCA}$ ) and incubating for $60 \mathrm{~min}$ at $4^{\circ} \mathrm{C}$. The supernatant was then discarded, and the plates were washed five times with deionized water and dried. One hundred microliters of SRB solution $(0.4 \%, \mathrm{w} / \mathrm{v}$, in $1 \%$ acetic acid) was added to each microtiter well and the culture was incubated for 10 min at room temperature. Unbound SRB was removed by washing five times with $1 \%$ acetic acid and the plates were air dried. The bond stain was solubilized with Tris buffer, and absorbance was read on an automated spectrophotometric plate reader at a single wavelength of $515 \mathrm{~nm}$. Cell growth was assessed in the SRB-staining assay by whole culture protein determination, showing sensitivity and reproducibility. Because of its large linearity range, the SRB assay is suitable to study not only low density cultures but also subconfluent monolayers and multilayer cell clusters containing large amounts of cells (12). Survival rates were calculated considering the plating efficiency of control cells simultaneously incubated for the same period of time as the irradiated cells. All cell lines at each density tested were irradiated as a uniform cell layer, since cells did 
not form clumps $24 \mathrm{~h}$ after seeding (the time needed for cells to recover from trypsin treatment). Therefore, cells were equally exposed to UV, since irradiation was carried out before cell aggregation.

DNA fragmentation analyses were performed as described by Obeid et al. (13) and Venable et al. (14) to provide an apoptotic index. Briefly, cells were seeded onto 6-well plates at a concentration of $60 \times 10^{3}$ cells/ $\mathrm{cm}^{2}$ and incubated for $24 \mathrm{~h}$ in RPMI 1640 medium ( $3 \mathrm{ml} /$ well) containing $10 \%$ FCS and $2.0 \mu \mathrm{Ci} / \mathrm{ml}$ of $\left[\right.$ methyl- $\left.{ }^{3} \mathrm{H}\right]$-thymidine $(20 \mathrm{Ci} / \mathrm{mmol}$; Amersham, Little Chalfont, England). Cells were washed twice with HBSS buffer, UV irradiated at room temperature as described above and replenished with medium without [methyl- ${ }^{3} \mathrm{H}$ ]-thymidine. Irradiated and control cells were then incubated for an additional $48 \mathrm{~h}$ and at the end of this period the medium $(m)$ was aspirated and counted in a liquid scintillation counter. The cells attached to the plate were lysed with PBS containing $1 \%$ Triton X-100 and $0.2 \mu \mathrm{M}$ EDTA and then centrifuged for 15 $\min$ at $14,000 \mathrm{rpm}$. Subsequently, both the supernatant $(s)$ and the remaining pellet $(p)$ containing larger DNA fragments were counted. The relative amount of medium and supernatant counts $(f)$ were calculated by summing the counts in the medium and in the supernatant and dividing by the total counts:

$$
f=(m+s) /(m+s+p)
$$

The percentage of DNA fragmentation (F) was obtained taking into account irradiated and control cells:

$$
\mathrm{F}=\left(f_{0}-f_{1}\right) \times 100
$$

where $f_{0}$ and $f_{1}$ are the relative amount of medium and supernatant counts of irradiated and non-irradiated cells, respectively.

The data were analyzed by the two-tailed Student $t$-test to establish significant intergroup differences. A P value less than 0.05 was considered to be significant.

\section{Results and Discussion}

The cell phenotypes of the A549, NCIH596 and NCI-H520 cell lines at dispersed density of a 72-h culture are shown in Figure 1A, 1B and 1C, respectively. A549 and NCIH596 cells displayed scattered cell distribution inside the cultured area, while NCIH520 cells formed aggregated foci even prior to confluence. By contrast, the confluent 72$\mathrm{h}$ cultures shown in Figure 1 indicate a high degree of cell-cell contact, exhibiting monolayers in A549 (1D) and NCI-H596 (1E) cell lines and an irregular multiple layer in NCIH520 (1F) cells.

In order to expose cells to UV radiation at several degrees of cell-cell contact, cells were inoculated at densities ranging from dispersion to confluence $\left(20-180 \times 10^{3}\right.$ cells/ $\mathrm{cm}^{2}$ ). The irradiations were carried out $24 \mathrm{~h}$ after cell seeding, the time needed for cells to recover from trypsin treatment. At this time cells were not organized in clumps but formed a single cell layer even at high density (avoiding irradiation of cells in aggregates). Growth inhibition as a function of cell density is presented in Figure 2 and indicates that the progressive increase in cell density led to increased resistance in A549, NCI-H596 and NCI-H520 cells. We observed that at confluent density $\left(180 \times 10^{3}\right.$ cells $\left./ \mathrm{cm}^{2}\right)$ all three cell lines displayed equivalent UV sensitivity. However, the NCI-H520 cells at $60 \times 10^{3}$ cells $/ \mathrm{cm}^{2}$ showed significantly lower UV sensitivity when compared to the others $(\mathrm{P}<0.01)$. At the same density $\left(60 \times 10^{3}\right.$ cells $/ \mathrm{cm}^{2}$ ) there were also no significant differences in growth rates among the cell lines $(\mathrm{P}<0.05$; Figure $3 \mathrm{~A})$.

The surviving fractions were determined by the SRB assay and, according to the method of Keepers et al. (15), SRB showed linearity in the absorbance $\mathrm{x}$ cell density function even for the high cell density endpoint (approximately $750 \times 10^{3}$ cells $/ \mathrm{cm}^{2}$ ). Pizao et al. (16) have established that the SRB-staining technique is suitable to assess 

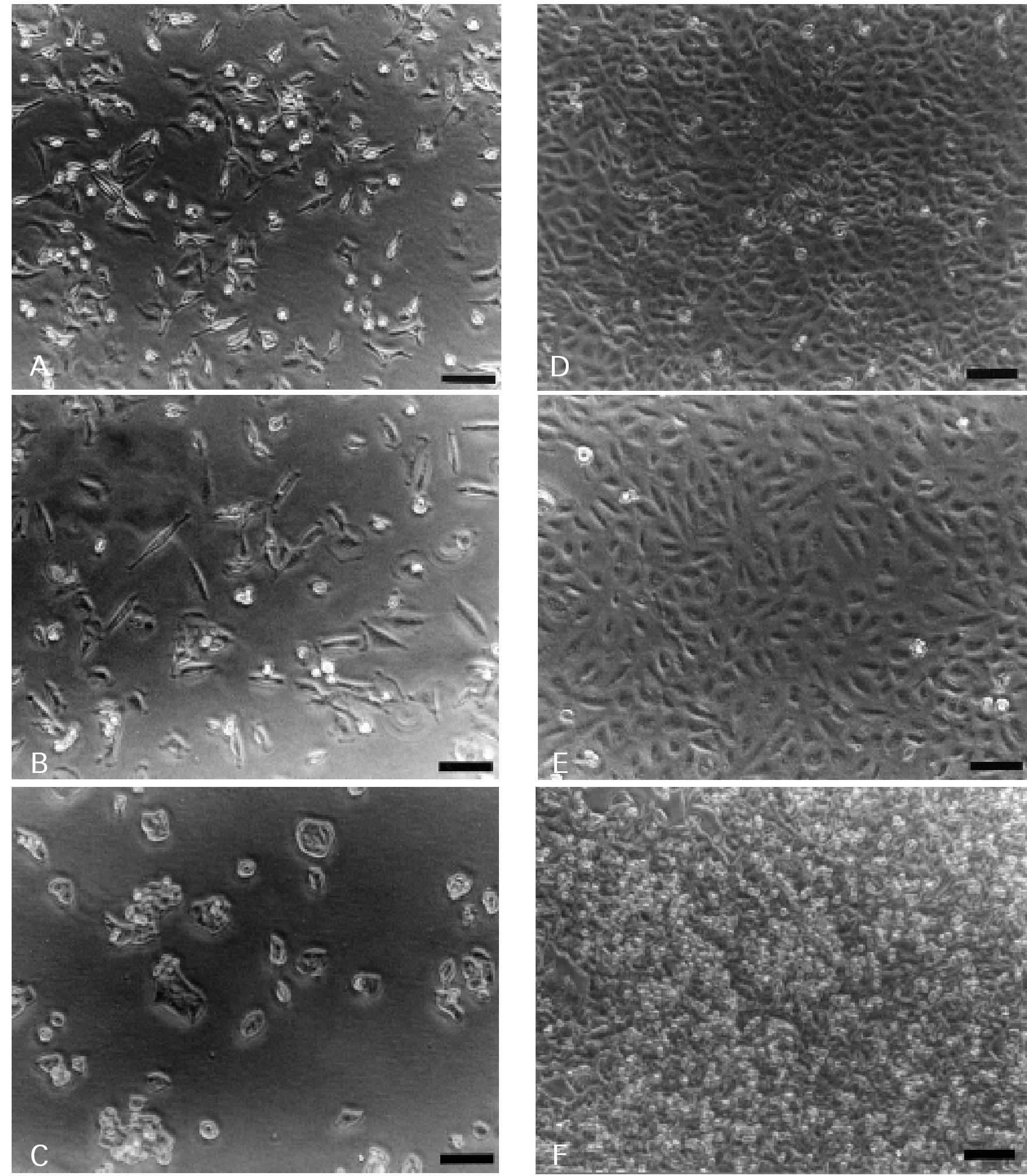

Figure 1. Phase contrast photomicrographs of A549 (A), NCl-H596 (B) and NCl-H520 (C) cell lines as dispersed cell cultures obtained after $72-\mathrm{h}$ incubation. Confluent cell cultures of A549, NCl-H596 and NCl-H520 after $72 \mathrm{~h}$ are shown in panels D, E and F, respectively. The bar length indicates approximately $100 \mu \mathrm{m}$. 
both growth and growth inhibition of postconfluent cultures in "V"-bottomed 96-well microtiter plates, which provide greater cell aggregation conditions than the plates used in our experiments.

However, we further investigated the growth inhibition disparity at $60 \times 10^{3}$ cells/ $\mathrm{cm}^{2}$ by verifying DNA sensitivity (Figure 3B). In contrast to NCI-H520, the A549 and NCI-H596 cell lines exhibited a high DNA fragmentation index, which is consistent with the cell growth inhibition values obtained by the SRB-staining technique.

Growing cells have been shown to be more susceptible to damage by antiproliferative agents when compared with cells in the stationary phase (17). However, in our cell panel the simple proliferative status did not appear to account for the disparity in UV sensitivity of the cells, since there were no significant differences in the growth rates among the lines at $60 \times 10^{3}$ cells $/ \mathrm{cm}^{2}$.

Kobayashi et al. (18) have reported that monodispersed mouse carcinoma cell lines are more sensitive to alkylating drugs than the cellular aggregates, and Kwok and Sutherland (19) showed that increased cellcell adhesion leads to cellular resistance to antiproliferative agents. Therefore, the inherent feature of NCI-H520 cells to form cellular foci even prior to confluence might provide further protection against UV damage. In contrast, the effects of UV radiation on both A549 and NCI-H596 cells might be enhanced due to a widespread isolated cell distribution at low plating densities (20-60 x $10^{3}$ cells $/ \mathrm{cm}^{2}$ ). According to Mathieu et al. (20), an increase in cell density (up to $20 \mathrm{x}$ $10^{3}$ cells $/ \mathrm{cm}^{2}$ ) in the NIH-OVCAR-3 cell line protects cells against apoptosis induced by TGF- $\beta 1$. Similarly, in our cell panel we observed a cell density-dependent survival of UV-irradiated cells.

Several studies on other cell lines have shown that cell culture phenotype can exclusively enhance cell growth, cell sensitivity and/or cell death-related pathways $(3,21,22)$.

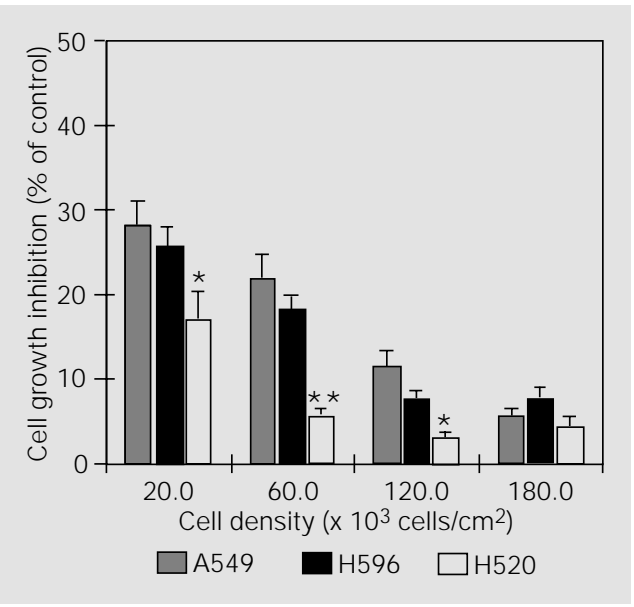

Figure 2. Growth inhibition of A549, NCl-H596 and NCl-H520 cell lines UV irradiated at different plating densities. Cells were pre-incubated for $24 \mathrm{~h}$, exposed to UV, and then incubated for an additional 48 $\mathrm{h}$ and counted. Cell number was determined by the sulforhodamine B-staining assay. The number of irradiated cells $(T)$ after the final 72 $\mathrm{h}$ was then compared to the number of non-irradiated cells (C) incubated simultaneously for the same 72-h period. Growth inhibition (GI) was determined by the formula $\mathrm{Gl}$ $=(1-T / C) \times 100$ (i.e., a T/C value of 0.3 means that cell culture grew only $30 \%$ of the control, giving a $\mathrm{GI}=70 \%$; alternatively, potential growth was inhibited by $70 \%)(8,12)$. All cell lines at each density tested were irradiated as a uniform cell layer, since the confluent cells did not form clumps $24 \mathrm{~h}$ after seeding (the time needed for cells to recover from trypsin treatment). Data are reported as the mean \pm SD of five independent determinations at each cell density $(\mathrm{N}=6)$. $* \mathrm{P}<0.05$ and $* * \mathrm{P}<0.01 \mathrm{com}$ pared to the others (Student t-test).

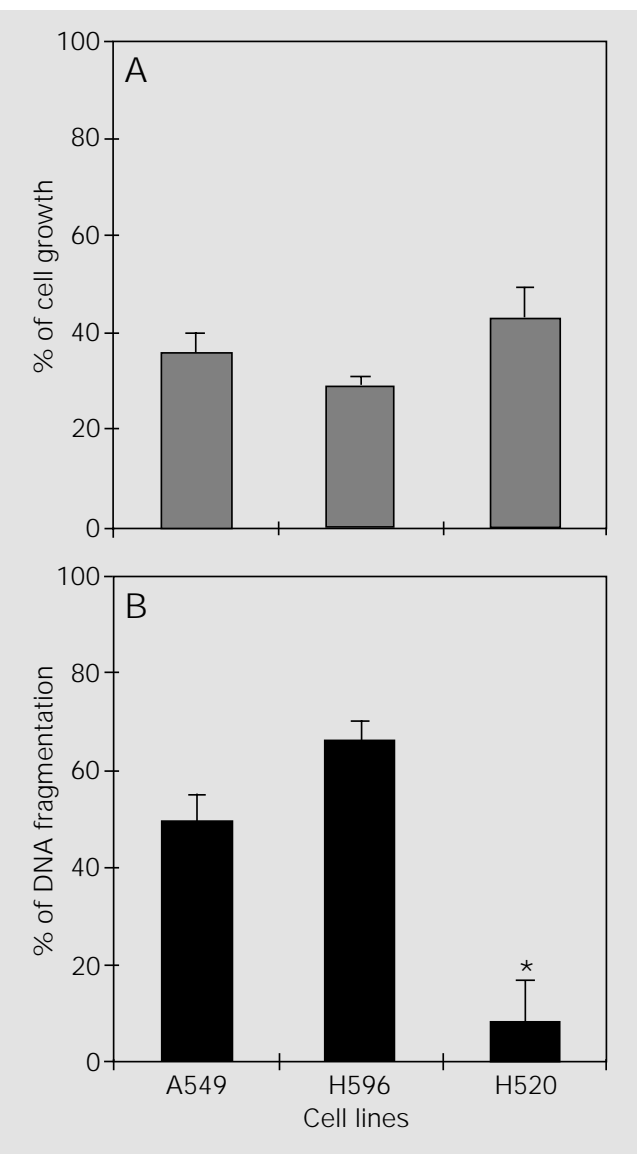

Figure 3. Proliferative status and DNA fragmentation of $\mathrm{A} 549, \mathrm{NCl}$ $\mathrm{H} 596$ and $\mathrm{NCl}-\mathrm{H} 520$ cell lines at 60 $\times 10^{3}$ cells $/ \mathrm{cm}^{2}$. A, Cells cultured for 24 and $48 \mathrm{~h}$ were counted by the sulforhodamine ß-staining assay. Percent cell growth is expressed as increased cell number between 24 and $48 \mathrm{~h}$ of incubation. $B$, Cells were pre-incubated for $24 \mathrm{~h}$ in medium containing [methyl- ${ }^{3} \mathrm{H}$ ]-thymidine, washed, and UV irradiated, and then new medium was replenished without [methyl- ${ }^{3} \mathrm{H}$ ]-thymidine. Irradiated and control cells were then incubated for an additional $48 \mathrm{~h}$ and at the end of this period the medium was aspirated and counted in a liquid scintillation counter. The cells attached to the plate were lysed and then centrifuged for $15 \mathrm{~min}$ at $14,000 \mathrm{rpm}$. Subsequently, both the supernatant and the remaining pellet containing larger DNA fragments were counted. Percent DNA fragmentation was calculated by summing the counts in the medium and the supematant and dividing by the total counts, taking into account irradiated and control cells as described in Material and Methods $(13,14)$. The cells did not form clumps $24 \mathrm{~h}$ after seeding (the time needed for cells to recover from trypsin treatment); therefore, all cell lines were irradiated as a uniform cell layer. Data are reported as the mean $\pm S D(N=3)$ and are representative of at least three experiments. ${ }^{*} \mathrm{P}<0.01$ compared to the others (Student t-test). 
We also previously found that, by preventing the formation of aggregates on a nonadherent substrate, the H520 cells become more sensitive to UV radiation, similarly to the H596 and A549 cell lines. In the same study, we also showed that in V-bottomed microtiter plates (an aggregated cell culture system) the cell lines exhibited equivalent growth rates and increased UV resistance (8). Accordingly, our current results suggest that cell distribution in the cultured area and the degree of intercellular contact may be associated with cell behavior, providing further evidence that cell phenotype is crucial to the way cells respond to environmental stimuli.

A molecular approach suggests that the p53 pathway may be associated with cell phenotype and intercellular contact regulation, as shown in at least three cell lines. Gloushankova et al. (23) reported that p53 dysfunction leads to decreased cell dispersion and elongation in transformed fibroblasts and epitheliocytes and Bates et al. (6) reported that $\mathrm{p} 53$ has been implicated in the contact-regulated cell death of LIM 1863 colon carcinoma cells. In our cell lines, p53 status was previously studied and both A549 and $\mathrm{H} 596$ cells displayed wild-type $\mathrm{p} 53$ with mRNA and protein levels equivalent to those of normal lung cells, while H520 presented vestigial levels of wild-type p53 $(24,25)$. Indeed, O'Connor et al. (26) showed a functional p53 pathway in the A549 cell line. Therefore, the low p53 levels of H520 and its clustered cell phenotype could coordinately account for H520 cell resistance to UV. Conversely, the functional p53 pathway in A549 cells, associated with their dispersed cell culture phenotype, could account for UV sensitivity. These studies agree with our results, but this proposal needs to be further investigated.

\section{Acknowledgments}

We thank Dr. Adriana B. da Rocha, Dr. Elena A. Bernard and Fábio Klamt for technical assistance.

\section{References}

1. Ruoslahti E (1997). Stretching is good for a cell. Science, 276: 1345-1346.

2. Folkmann J \& Moscona A (1978). Role of cell shape in growth control. Nature, 273: 345-349.

3. Chen CS, Mrksich M, Huang S, Whitesides GM \& Ingber DE (1997). Geometric control of cell life and death. Science, 276: 1425-1428.

4. Ingber DE (1990). Fibronectin controls capillary endothelial cell growth by modulating cell shape. Proceedings of the National Academy of Sciences, USA, 87: 3579-3583.

5. Olive PL \& Durand RE (1994). Drug and radiation resistance in spheroids: cell contact and kinetics. Cancer and Metastasis Reviews, 13: 121-138.

6. Bates RC, Buret A, van Helden DF, Horton MA \& Burns GF (1994). Apoptosis induced by inhibition of intercellular contact. J ournal of Cell Biology, 125: 403415.

7. Kataoka S, Naito M, Fujita N, Ishii H,
Yamori T, Nakajima M \& Tsuruo T (1993). Control of apoptosis and growth of malignant $\mathrm{T}$ lymphoma cells by lymph node stromal cells. Experimental Cell Research, 207: 271-276.

8. Castro MA, Schwartsmann G, Bemardt EA \& Moreira JCF (1999). Phenotype modulation of cellular UV-sensitivity. Cancer Letters, 145: 65-72.

9. Banks-Schlegel SP, Gazdar AF \& Harris CC (1985). Intermediate filament and cross-linked envelope expression in human lung tumor cell lines. Cancer Research, 45: 1187-1197.

10. Levitt ML, Gazdar AF, Oie HK, Schuller H $\&$ Thacher SM (1990). Cross-linked envelope-related markers for squamous differentiation in human lung cancer cell lines. Cancer Research, 50: 120-128.

11. Begg AC \& Hofland I (1991). Cell kinetic analysis of mixed populations using threecolor fluorescence flow cytometry. Cytometry, 12: 445-454.

12. Skehan $P$, Storeng $R$, Scudiero D, Monks
A, McMahon J, Vistica D, Warren JT, Bokesch H, Kenney S \& Boyd MR (1990). New colorimetric cytotoxicity assay for anticancer-drug screening. J ournal of the $\mathrm{Na}$ tional Cancer Institute, 82: 1107-1112.

13. Obeid LM, Linardic CM, Karolak LA \& Hannun YA (1993). Programmed cell death induced by ceramide. Science, 259: 1769-1771.

14. Venable ME, Lee JY, Smyth MJ, Bielawska A \& Obeid LM (1995). Role of ceramide in cellular senescence. J ournal of Biological Chemistry, 270: 3070130708.

15. Keepers YP, Pizao PE, Peters GJ , van ArkOtte J , Winograd B \& Pinedo HM (1991). Comparison of the sulforhodamine $B$ protein and tetrazolium (MTT) assays for in vitro chemosensitivity test. European J ournal of Cancer, 27: 897-900.

16. Pizao PE, Lyaru DM, Peters GJ , van ArkOtte J , Winograd B, Giaccone G \& Pinedo HM (1992). Growth, morphology and chemosensitivity studies on postconflu- 
ent cells cultured in "V" -bottomed microtiter plates. British J ournal of Cancer, 66: 660-665.

17. DeVita VTJ, Hellman S \& Rosenberg SA (1993). Cancer: Principles and Practice of Oncology. 4th edn. J.B. Lippincott Co., Philadelphia.

18. Kobayashi H, Man S, Graham CH, Kapitain SJ , Teicher BA \& Kerbel RS (1993). Acquired multicellular-mediated resistance to alkylating agents in cancer. Proceedings of the National Academy of Sciences, USA, 90: 3294-3298.

19. Kwok TT \& Sutherland RM (1991). The influence of cell-cell contact on radiosensitivity of human squamous carcinoma cells. Radiation Research, 126: 52-57.

20. Mathieu C, J ozan S, Mazars P, Côme MG, Moisand A \& Valette A (1995). Densitydependent induction of apoptosis by transforming growth factor- $\beta 1$ in a human ovarian carcinoma cell line. Experimental Cell Research, 216: 13-20.

21. Reddy NMS, Kapiszewska M \& Lange CS (1992). Detection of X-ray damage repair by the immediate versus delayed plating technique is dependent on cell shape and cell concentration. Scanning Microscopy, 6: 543-559.

22. Leung LK, Do L \& Wang TTY (1998). Regulation of death promoter Bak expression by cell density and 17ß-estradiol in MCF-7 cells. Cancer Letters, 124: 47-52.

23. Gloushankova N, Ossovskaya V, Vasiliev J, Chumakov P \& Kopnin B (1997). Changes in p53 expression can modify cell shape of ras-transformed fibroblasts and epitheliocytes. Oncogene, 15: 29852989.

24. Noble J R, Willetts KE, Mercer WE \& Reddel RR (1992). Effects of exogenous wild-type p53 on a human lung carcinoma cell line with endogenous wild-type p53. Experimental Cell Research, 203: 297304.

25. Takahashi T, Nau MM, Chiba I, Birrer MJ Rosenberg RK, Vinocour $M$, Levitt $M$, Pass H, Gazdar AF \& Minna J D (1989). p53: a frequent target for genetic abnormalities in lung cancer. Science, 246: 491494.

26. O'Connor PM, J ackman J, Bae I, Myers TG, Fan S, Mutoh M, Scudiero DA, Monks A, Sausville EA, Weinstein J N, Friend S, Fornance J r AJ \& Kohn KW (1997). Characterization of the p53 tumor suppressor pathway in cell lines of the National Cancer Institute anticancer drug screen and correlations with the growth-inhibitory potency of 123 anticancer agents. Cancer Research, 57: 4285-4300. 